\title{
Determination of the androgen receptor status of circulating tumour cells in metastatic breast cancer patients
}

Natalia Krawczyk ${ }^{1 *}$ D, Melissa Neubacher ${ }^{1}$, Franziska Meier-Stiegen ${ }^{1}$, Hans Neubauer $^{1}$, Dieter Niederacher ${ }^{1}$, Eugen Ruckhäberle', Svjetlana Mohrmann', Jürgen Hoffmann'1, Thomas Kaleta', Malgorzata Banys-Paluchowski², Petra Reinecke ${ }^{3}$, Irene Esposito ${ }^{3}$, Wolfgang Janni ${ }^{4}$ and Tanja Fehm ${ }^{1}$

\begin{abstract}
Background: The prognostic relevance of circulating tumour cells (CTCs) in metastatic breast cancer (MBC) patients has been confirmed by several clinical trials. However, predictive blood-based biomarkers for stratification of patients for targeted therapy are still lacking. The DETECT studies explore the utility of CTC phenotype for treatment decisions in patients with HER2 negative MBC. Associated with this concept is a plethora of translational projects aiming to identify potential predictive biomarkers. The androgen receptor (AR) is expressed in over $70 \%$ of hormone receptor-positive and up-to $45 \%$ of triple-negative tumours. Studies has indicated the promising nature of AR as a new therapy target with a clinical benefit rate for anti-AR treatment in MBC patients up to 25\% The aim of this analysis was the characterization of CTCs regarding the expression of the AR using immunofluorescence.

Methods: MBC patients were screened for the HER2-status of CTCs in the DETECT studies. In a subset of CTCpositive patients $(n=67)$ an additional blood sample was used for immunomagnetic enrichment of CTCs using the CellSearch ${ }^{\oplus}$ Profile Kit prior to transfer of the cells onto cytospin slides. Establishment of immunofluorescence staining for the AR was performed using prostate cancer cell lines LNCaP and DU145 as positive and negative control, respectively. Staining of DAPI, pan-cytokeratin (CK) and CD45 was applied to identify nucleated epithelial cells as CTCS and to exclude leucocytes.

Results: Co-staining of the AR, CK and CD45 according to the above mentioned workflow has been successfully established using cell lines with known AR expression spiked into the blood samples from healthy donors. For this translational project, samples were analysed from 67 patients participating in the DETECT studies. At least one CTC was detected in 37 out of 67 patients (56\%). In 16 of these 37 patients (43\%) AR-positive CTCs were detected. In eight out of 25 patients (32\%) with more than one CTC, AR-positive and AR-negative CTCs were observed.
\end{abstract}

Conclusion: In $43 \%$ of the analysed CTC samples from patients with MBC the AR expression has been detected. The predictive value of AR expression in CTCS remains to be evaluated in further trials.

Keywords: Predictive marker, Androgen receptor, Metastatic breast cancer, Circulating tumour cells

\footnotetext{
* Correspondence: natalia.krawczyk@med.uni-duesseldorf.de

'Department of Obstetrics and Gynaecology, University of Duesseldorf,

Moorenstr. 5, 40225 Duesseldorf, Germany

Full list of author information is available at the end of the article
}

(c) The Author(s). 2019 Open Access This article is distributed under the terms of the Creative Commons Attribution 4.0 International License (http://creativecommons.org/licenses/by/4.0/), which permits unrestricted use, distribution, and reproduction in any medium, provided you give appropriate credit to the original author(s) and the source, provide a link to the Creative Commons license, and indicate if changes were made. The Creative Commons Public Domain Dedication waiver (http://creativecommons.org/publicdomain/zero/1.0/) applies to the data made available in this article, unless otherwise stated. 


\section{Background}

Breast cancer $(\mathrm{BC})$ is the most common malignancy in women, with almost 1.7 million new cases diagnosed per year [1]. While localized disease has become increasingly treatable, with an average 5-year survival rate of approximately 90\%, metastatic breast cancer (MBC) still carries a very poor prognosis. Despite a complete removal of the tumour and adequate systemic treatment, $25-30 \%$ of primary BC patients suffer from a distant recurrence during the follow-up, making metastatic $\mathrm{BC}$ the second leading cause of cancer-related death among women worldwide [1-3]. Therefore, novel therapeutic targets and innovative systemic treatment approaches in MBC are still desperately required. The androgen receptor (AR) is a ligand-dependent transcription factor belonging to the nuclear steroid hormone receptor family, thus sharing several features with the oestrogen (ER) and progesterone receptors. In its unbound state, the AR is located in the cytoplasm in complex with heat shock protein 90 and other chaperone proteins. Upon ligand stimulation, the AR undergoes dimerization and translocates to the nucleus, where it regulates transcription by binding to target genes [4-6]. AR expression has been reported in over $70 \%$ of all primary BCs and it is more often detected in ER-positive than in ER-negative tumours. However, up to $45 \%$ of triple negative $\mathrm{BC}$ patients express the AR [7-14]. The role of the AR in BC has not yet been completely elucidated and seems to depend on tumour subtype. Several in vitro studies have shown a divergent effect of androgens on cell proliferation in $\mathrm{BC}$ cell lines $[15,16]$. In the presence of $\mathrm{ER} \alpha$, the AR can either have proliferative or anti-proliferative activity, depending on the level of the co-expressed ER $\alpha$ and the availability of the respective ligand [17-19], Moreover, an AR-overexpression in HR-positive $\mathrm{BC}$ has been shown to be associated with resistance to tamoxifen, which may be reversed by an anti-androgen treatment [20]. In contrast, in HER2-positive and triple negative $\mathrm{BC}$ a proliferative function of the AR seems to be consistent [21]. The above indicates a strong rationale to explore $\mathrm{AR}$ expression as a therapeutic target in all subtypes of $\mathrm{BC}$. Anti-AR treatment has recently been evaluated in two multicentre phase II studies on $\mathrm{MBC}$ patients showing promising results with a clinical benefit rate of up to $25 \%$ [22, 23]. The ongoing trials on antiandrogen treatment in breast cancer are summarized in Table 1. However, none of these trials included the ARstatus of CTCs for stratification. Circulating tumour cells (CTCs) can be detected in approximately $40-80 \%$ of $\mathrm{MBC}$ patients and predict impaired clinical outcome

Table 1 Ongoing trials on anti-androgen treatment in breast cancer

\begin{tabular}{|c|c|c|c|c|c|}
\hline Study & Status & $\begin{array}{l}\text { Estimated } \\
\text { Enrollment }\end{array}$ & Condition & Intervention & Primary Endpoint \\
\hline $\begin{array}{l}\text { NCT00468715 (Phase II) non- } \\
\text { randomized }\end{array}$ & $\begin{array}{l}\text { Active, not } \\
\text { recruiting }\end{array}$ & 28 & $A R+/ H R-M B C$ & - Bicalutamide & $\begin{array}{l}\text { CBR }^{a} \text { (observed CBR of } \\
19 \%[22])\end{array}$ \\
\hline $\begin{array}{l}\text { NCT01889238 (Phase II) non- } \\
\text { randomized }\end{array}$ & $\begin{array}{l}\text { Active, not } \\
\text { recruiting }\end{array}$ & 118 & $\begin{array}{l}\text { AR+/ triple negative } \\
A B C\end{array}$ & - Enzalutamide & $\begin{array}{l}\text { CBR (observed CBR of } \\
25 \%[24])\end{array}$ \\
\hline $\begin{array}{l}\text { ENDEAR trial NCT02929576 } \\
\text { (Phase III) }\end{array}$ & withdrawn & 780 & Triple negative $A B C$ & $\begin{array}{l}\text { - Enzalutamide vs } \\
\text { - Paclitaxel vs } \\
\text { - combination }\end{array}$ & PFS \\
\hline $\begin{array}{l}\text { NCT02750358 (phase II) non- } \\
\text { randomized, single agent }\end{array}$ & $\begin{array}{l}\text { Active, not } \\
\text { recruiting }\end{array}$ & 200 & $\begin{array}{l}\text { AR+ / triple negative } \\
\text { ESBC }\end{array}$ & - Enzalutamide & $\begin{array}{l}\text { treatment } \\
\text { discontinuation rate/ } \\
\text { feasibility }\end{array}$ \\
\hline $\begin{array}{l}\text { NCT02689427 (phase Ilb) non- } \\
\text { randomized }\end{array}$ & recruiting & 37 & $\begin{array}{l}\text { AR+ / triple negative } \\
\mathrm{ESBC}\end{array}$ & $\begin{array}{l}\text { - Enzalutamide plus Paclitaxel in } \\
\text { neoadjuvant setting }\end{array}$ & PCR rate \\
\hline $\begin{array}{l}\text { NCT02007512 (phase II) } \\
\text { randomized }\end{array}$ & $\begin{array}{l}\text { Active, not } \\
\text { recruiting }\end{array}$ & 247 & $\mathrm{HR}+\mathrm{HER} 2-\mathrm{ABC}$ & - Exemestan +/- Enzalutamide & PFS \\
\hline $\begin{array}{l}\text { NCT02463032 (Phase II) } \\
\text { randomized }\end{array}$ & $\begin{array}{l}\text { Active, not } \\
\text { recruiting }\end{array}$ & 88 & $E R+/ A R+A B C$ & $\begin{array}{l}\text { - GTx-024 (Enobosarm) } \\
\text { - SARM } \\
\text { - } 9 \text { vs. } 18 \mathrm{mg} .\end{array}$ & CBR \\
\hline $\begin{array}{l}\text { NCT01990209 (phase II) non- } \\
\text { randomized }\end{array}$ & $\begin{array}{l}\text { Active, not } \\
\text { recruiting }\end{array}$ & 86 & $\begin{array}{l}\mathrm{HR}+/ \mathrm{AR}+\text { or triple } \\
\text { negative /AR+ MBC }\end{array}$ & $\begin{array}{l}\text { - TAK-700 (orteronel) a nonsteroi- } \\
\text { dal inhibitor of CYP17A1 }\end{array}$ & $\begin{array}{l}\mathrm{RR}^{\mathrm{b}} \\
\mathrm{DCR}\end{array}$ \\
\hline $\begin{array}{l}\text { NCT02067741 SAKK21/12 } \\
\text { (Phase II) non- randomized }\end{array}$ & $\begin{array}{l}\text { active, not } \\
\text { recruiting }\end{array}$ & 90 & $\begin{array}{l}\mathrm{HR}+/ \mathrm{HER} 2-\text { or triple } \\
\text { negative/ } \mathrm{AR}+\mathrm{ABC}\end{array}$ & $\begin{array}{l}\text { - transdermal CR1447 (4-OH- } \\
\text { testosterone) }\end{array}$ & DCR \\
\hline $\begin{array}{l}\text { NCT02091960 (Phase II) non- } \\
\text { randomized }\end{array}$ & $\begin{array}{l}\text { Active, not } \\
\text { recruiting }\end{array}$ & 103 & $\mathrm{HER} 2+/ \mathrm{AR}+\mathrm{ABC}$ & - Enzalutamide + trastuzumab & CBR \\
\hline
\end{tabular}

$A R$ androgen receptor, $E R$ oestrogen receptor, $P R$ progesteron receptor, $H R$ hormone receptor, $H E R 2$ human epidermal growth factor receptor 2:, $C B R$ Clinical benefit rate, ${ }^{a}$ defined as proportion of patients with stability, partial response and complete response assessed by RECIST v1.1 criteria, $P F S$ progression free survival, ESBC early stage breast cancer, SARM selective androgen receptor modulator, $A B C$ advanced breast cancer (metastatic or locally advanced), RR responder rate, ${ }^{b}$ defined as the percentage of complete and partial responders (CR + PR) assessed by RECIST v1.1 criteria, $D C R$ disease control rate, ${ }^{\mathrm{c}}$ defined as the percentage of patients who do not exhibit progression 
[25]. Beyond their prognostic significance, CTCs may serve as a "liquid biopsy", since their expression profile is assumed to most adequately reflect the phenotype of the presently dominant tumour cell population in metastatic disease. Moreover, a CTC phenotype may potentially predict the response to treatment, thereby making these cells not only a valuable source of cancer material but also a potential target for a therapeutic intervention [26]. The clinical utility of CTCs in driving treatment decisions is currently being evaluated within the DETECT studies [27]. The aim of the present substudy was to evaluate the AR status of CTCs in a cohort of MBC.

\section{Methods}

\section{Patient material}

Blood samples from $67 \mathrm{MBC}$ patients, screened within the German DETECT III/IV trials (III: NCT01619111, IV: NCT02035813) between 2012 and 2017 for the HER2-status of CTCs, were eligible for this analysis (for more information: www.detect-studien.de). DETECT III/ IV study trial is a multicenter study program for patients with HER2-negative MBC and circulating tumor cells. The main objective of this study is to evaluate the efficacy of personalized breast cancer therapy based on the presence and phenotype of CTCs. The flow chart of our substudy is presented in Fig. 1. Written informed consent was obtained from all participating patients and the study was approved by the Ethical Committee of the Eberhard Karls University of Tuebingen (responsible for DETECT III: 525/2011AMG1) and the local Ethical

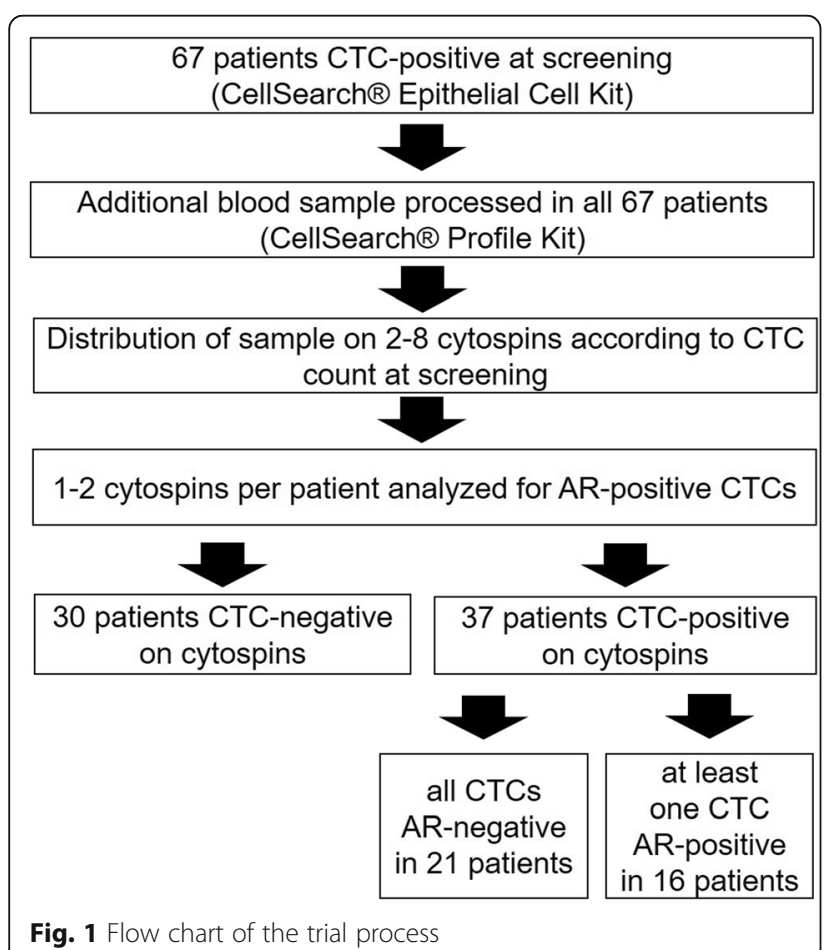

Fig. 1 Flow chart of the trial process
Committee of the Heinrich Heine University of Duesseldorf (DETECT III: MC-531; DETECT IV: MC-LKP668).

\section{CTC enrichment and cytospin preparation}

Blood samples were drawn into $10 \mathrm{ml}$ CellSave tubes (Menarini Silicon Biosystems), maintained at room temperature and processed within $72 \mathrm{~h}$ after collection. The CellSearch $^{\odot}$ Epithelial Cell Kit (Menarini Silicon Biosystems) was used routinely for enrichment and enumeration of CTCs as described previously [28]. In a subset of CTCpositive patients an additional blood sample was processed using the CellSearch ${ }^{\oplus}$ Profile Kit (Menarini Silicon Biosystems) to enrich tumour cells expressing the epithelial cell adhesion molecule (EpCAM) immunomagnetically without further labelling or enumerating the cells. $10 \mathrm{~mL}$ of blood from the CellSave Preservative Tube was transferred into a correspondingly labelled $15 \mathrm{~mL}$ CELLSEARCH ${ }^{\odot}$ Conical Centrifuge Tube with $6.5 \mathrm{~mL}$ of dilution buffer, consisting of phosphate buffered saline (PBS), $0.5 \%$ bovine serum albumin and $0.1 \%$ sodium azide. The sample was centrifuged at $800 \mathrm{x} \mathrm{g}$ for $10 \mathrm{~min}$ at room temperature and processed on the CELLTRACKS ${ }^{\circledast}$ AUTOPREP $^{\oplus}$ System within $1 \mathrm{~h}$. The magnetic incubation steps were performed and the vast majority of leukocytes and other blood components were depleted from the final sample. Using a ROTOFIX 32 A centrifuge $(800 \mathrm{rpm}, 2 \mathrm{~min}$; Hettich $\mathrm{GmbH} \&$ Co.KG, Tuttlingen, Germany) $400 \mu \mathrm{l}$ of the white blood celldepleted cell suspension were spun onto a glass slide. The slides were air-dried overnight at room temperature and stored at $-20^{\circ} \mathrm{C}$. One to two cytospins per patient was analysed for AR-positive CTCs. Control cytospins with ARpositive LNCaP cells and AR-negative Du145 cells mixed with peripheral blood mononuclear cells (PBMCs) from a healthy volunteer were similarly prepared, stored and fixed.

\section{Androgen receptor staining}

Cytospins were thawed at room temperature in a humid chamber for approximately $20 \mathrm{~min}$ and fixed with CellSave (Veridex, Warren, NJ, USA) for $10 \mathrm{~min}$. After an initial wash step with PBS (Sigma, Munich, Germany), cells were permeabilized with PBS containing 0.1\% Triton $\mathrm{X}-100$ for a period of $10 \mathrm{~min}$ prior to blocking with Protein Block solution (DAKO, CA, USA) for another $10 \mathrm{~min}$. The immunofluorescence stainings were performed using the Androgen Receptor (D6F11) XP rabbit monoclonal antibody (1:100, Cell Signaling Technologies Inc., Cambridge UK) and the pan-cytokeratin (CK) antibody (C11) directly conjugated to fluorescein isothiocyanate (FITC) (1:100, Sigma, Munich, Germany) for 60 min. Cytospins were subsequently incubated with a secondary donkey anti-rabbit antibody, labelled with Alexa Fluor 594 (1:500, Invitrogen Molecular Probes, Carlsbad, CA, USA) and an Alexa Fluor 647-conjugated CD45 
antibody (35-Z6) (1:20, Santa Cruz Biotechnology, Dallas, TX, USA) for $30 \mathrm{~min}$. Nuclear DNA staining was performed with 4'6-diamidino-2-phenylindole (DAPI) in mounting media (Vector Laboratories, Burlingame, CA, USA). Preparations of the prostate cancer cell line LNCaP mixed with PBMCs from a healthy volunteer served as a positive control for CK and AR staining. The AR-negative control slides of Du145/PBMC mixtures were also included with each batch of samples. CK positive, CD45 negative cells that contained an intact nucleus (DAPI positive) were identified as CTCs. Positive and negative control stainings are shown in Fig. 2.

\section{Statistical analysis}

The chi-squared test was used to evaluate the association between CTCs and clinicopathological factors. Statistical analysis was performed by SPSS (version 25). Values of $p<0.05$ were considered statistically significant.

\section{Results}

Patients` characteristics

Peripheral blood from $67 \mathrm{MBC}$ patients screened for participation in the DETECT trial were eligible for this study. 55 patients (82\%) had hormone receptor (HR)positive/HER2-negative tumours, two cases (3\%) had immunohistochemistry stainings indicating HR-positive/ HER2-positive disease, and 10 patients (15\%) had a triple negative breast cancer (TNBC). In 26 patients (40\%) the blood draw was performed prior to the first line therapy for metastatic disease. The remaining 41 patients (60\%) had progressive metastatic disease at blood sampling. The clinical data of the patients are summarized in Table 2.

\section{CTC detection and AR expression in CTCs}

At least one CTC was detected in 37 patients (56\%). The CTC count ranged from 1 to 101 cells. In 16 out of the 37 CTC-positive patients (43\%), AR-positive CTCs could be detected. The percentage of AR-positive CTCs among

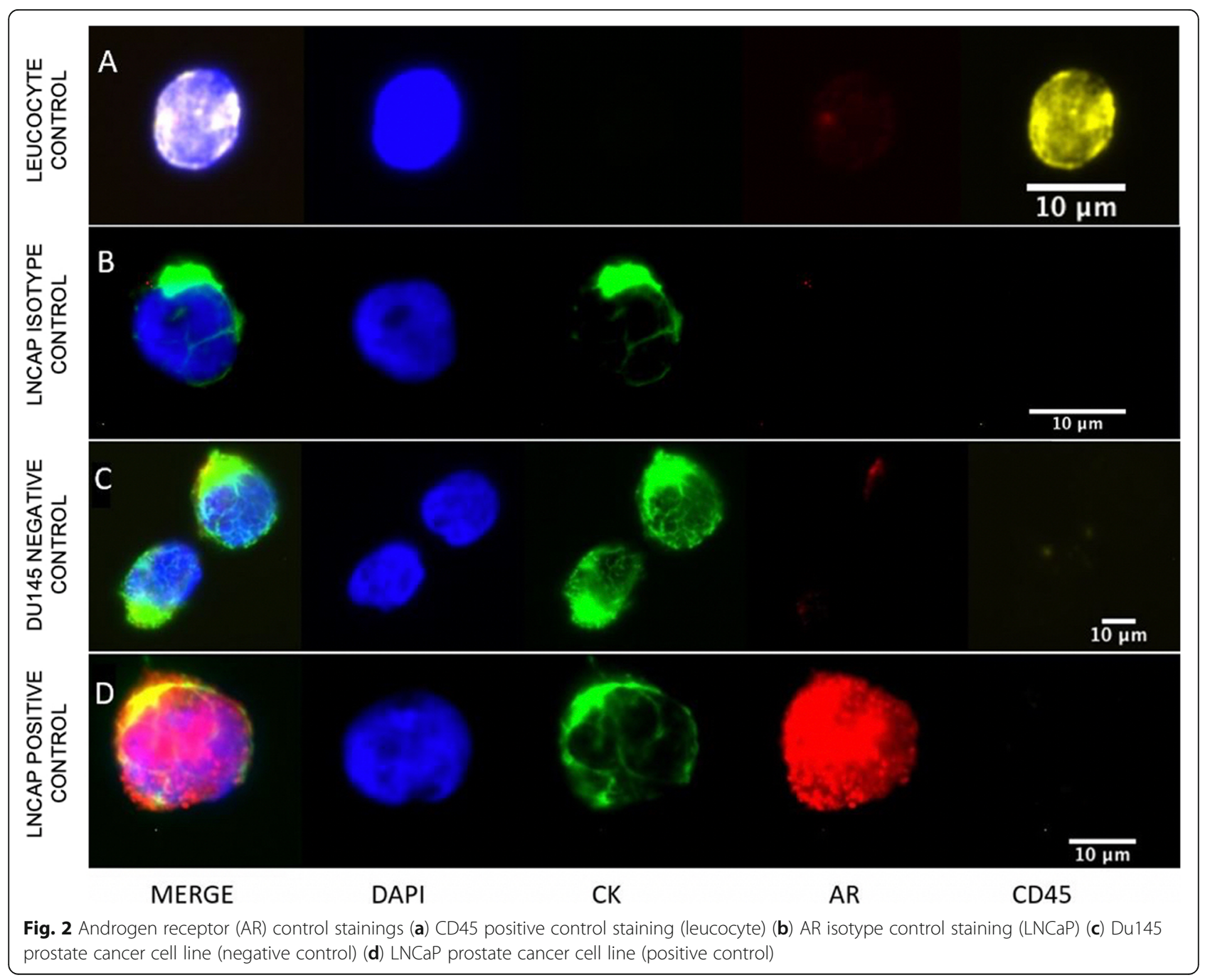


Table 2 Clinical data of patients

\begin{tabular}{|c|c|c|c|c|c|}
\hline & $\mathrm{nN}=67$ & CTC positive (\%) & $p$-value & AR-positive CTC (\%) & p-value \\
\hline Total & 67 & $37(55)$ & & $16(43)$ & \\
\hline Menopausal status & & & 0.40 & & 0.68 \\
\hline premenopausal & 12 & $7(58)$ & & $4(57)$ & \\
\hline postmenopausal & 53 & $28(53)$ & & $11(39)$ & \\
\hline unknown & 2 & $2(100)$ & & $1(50)$ & \\
\hline Line of treatment & & & 0.75 & & 0.30 \\
\hline $1 \mathrm{st}$ & 26 & $15(58)$ & & $8(53)$ & \\
\hline$\geq 2$ nd & 41 & $22(54)$ & & $8(36)$ & \\
\hline $\mathrm{IHC}$ tumour type & & & 0.94 & & 0.56 \\
\hline TNBC & 10 & $6(60)$ & & $2(33)$ & \\
\hline HR+/HER2- & 55 & $30(54)$ & & $14(47)$ & \\
\hline $\mathrm{HR}+/ \mathrm{HER} 2+{ }^{\mathrm{a}}$ & 2 & $1(50)$ & & 0 & \\
\hline Site of metastasis & & & 0.65 & & 0.44 \\
\hline bone only & 14 & $8(57)$ & & $4(50)$ & \\
\hline other site & 52 & $28(54)$ & & $11(39)$ & \\
\hline unknown & 1 & $1(100)$ & & $1(100)$ & \\
\hline
\end{tabular}

${ }_{\text {ascreening failure }}$

CTCs detected per patient ranged from 0 to $100 \%$ (mean 35.5, 95\%-CI: $21.4-49.6 \%)$. In 5 out of 16 patients (31\%) with AR-positive CTCs, the AR was localized in the nucleus whereas in 10 patients (62.5\%) the AR signal was detected in the cytoplasm. Both nuclear and cytoplasmic localization were observed in only one patient (6.5\%). Heterogenic AR localization in CTCs is depicted in Fig. 3. Among the 25 patients with more than one CTC, 14 had only AR-negative CTCs, and 3 had only ARpositive CTCs. In the remaining 8 patients (32\%), ARpositive and AR-negative CTCs could be detected and the AR-positivity rate ranged from 12 to $83 \%$. The characteristics of CTC-positive patients are demonstrated in Table 3.

\section{Discussion}

There is growing evidence on the potential role of androgens and the AR in the pathogenesis of breast cancer. The majority of ER-positive breast cancers and up to $45 \%$ of TNBC express the AR in tumour tissue, making this biomarker an interesting therapeutic target [7-14]. AR targeting drugs, like bicalutamide or enzalutamide, are currently being evaluated in clinical trials focussing on AR-positive MBC, with favourable clinical benefit

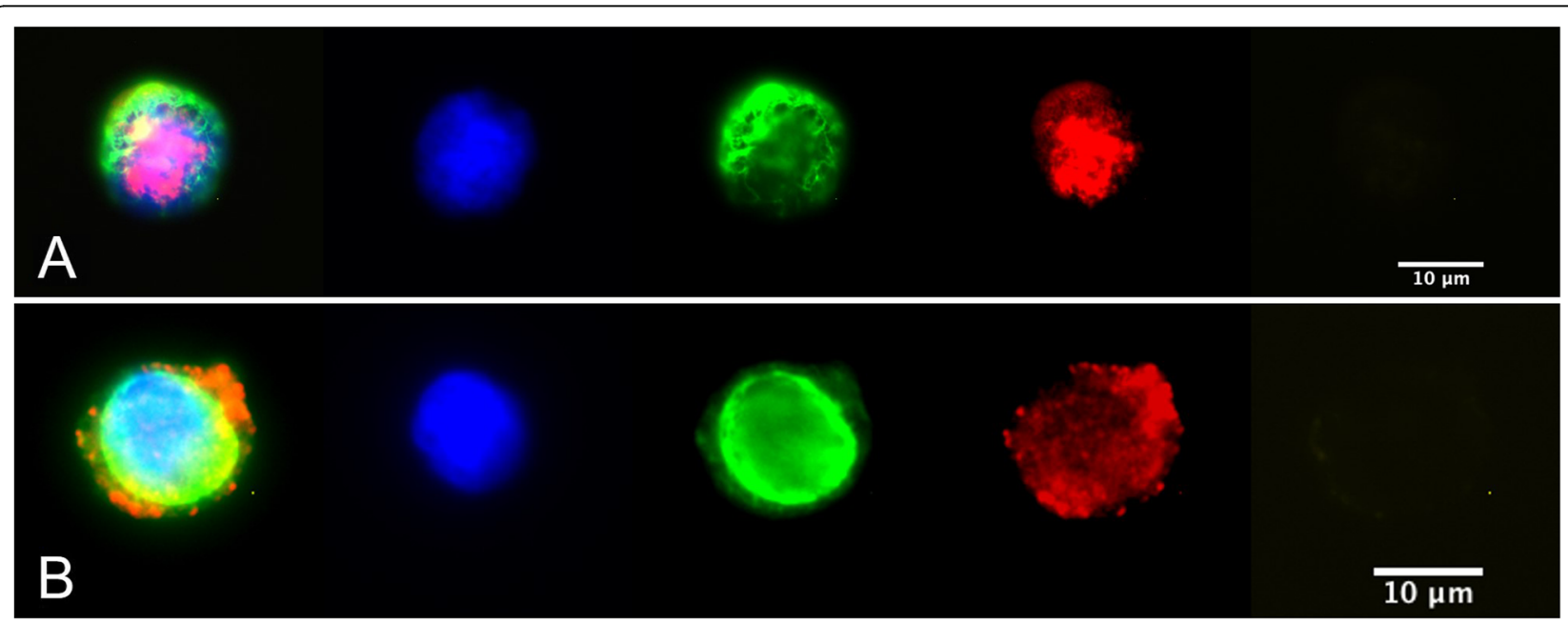

Fig. 3 androgen receptor (AR) staining of CTCs in metastatic breast cancer patients (a) AR-positive nuclear staining (b) AR-positive cytoplasmic staining 
Table 3 Characteristics of CTC-positive patients

\begin{tabular}{|c|c|c|c|c|c|c|c|}
\hline Patient & $\begin{array}{l}\text { Menopausal } \\
\text { status }\end{array}$ & $\begin{array}{l}\text { IHC tumour } \\
\text { type }\end{array}$ & $\begin{array}{l}\text { Number of previously received } \\
\text { treatment lines }^{a}\end{array}$ & Metastatic site & $\begin{array}{l}\text { CTC } \\
\text { count }\end{array}$ & $\begin{array}{l}\text { AR positive CTC } \\
(\%)\end{array}$ & AR localization \\
\hline 1 & postmenopausal & HR+ HER2- & 1 & bone visceral & 101 & $84(83)$ & $\begin{array}{l}\text { cytoplasm/ } \\
\text { nucleus }\end{array}$ \\
\hline 2 & premenopausal & HR+ HER2- & 0 & bone & 13 & $7(54)$ & cytoplasm \\
\hline 3 & postmenopausal & HR+ HER2- & 2 & bone visceral & 10 & $3(30)$ & cytoplasm \\
\hline 4 & postmenopausal & $\begin{array}{l}\text { HR+ } \\
\text { HER2- }\end{array}$ & 2 & bone & 9 & $0(0)$ & - \\
\hline 5 & premenopausal & TNBC & 0 & bone visceral & 8 & $1(12)$ & cytoplasm \\
\hline 6 & premenopausal & HR+ HER2- & 0 & bone & 7 & $7(100)$ & nucleus \\
\hline 7 & unknown & HR+ HER2- & 0 & unknown & 4 & $3(75)$ & cytoplasm \\
\hline 8 & postmenopausal & HR+ HER2- & 4 & bone visceral & 4 & $3(75)$ & cytoplasm \\
\hline 9 & postmenopausal & HR+ HER2- & 0 & bone & 3 & $1(33)$ & cytoplasm \\
\hline 10 & postmenopausal & HR+ HER2- & 7 & bone & 3 & $3(100)$ & cytoplasm \\
\hline 11 & postmenopausal & HR+ HER2- & 0 & visceral & 3 & $3(100)$ & cytoplasm \\
\hline 12 & postmenopausal & HR+ HER2- & 3 & bone visceral & 3 & $0(0)$ & - \\
\hline 13 & postmenopausal & HR+ HER2- & 4 & bone visceral & 3 & $0(0)$ & - \\
\hline 14 & postmenopausal & HR+ HER2- & 1 & bone visceral & 3 & $0(0)$ & - \\
\hline 15 & unknown & HR+ HER2+ & 2 & visceral & 3 & $0(0)$ & - \\
\hline 16 & premenopausal & HR+ HER2- & 0 & $\begin{array}{l}\text { bone lymph } \\
\text { nodes }\end{array}$ & 3 & $0(0)$ & - \\
\hline 17 & premenopausal & TNBC & 1 & bone visceral & 2 & $1(50)$ & nucleus \\
\hline 18 & postmenopausal & HR+ HER2- & 1 & bone & 2 & 0 & - \\
\hline 19 & postmenopausal & HR+ HER2- & 2 & bone visceral & 2 & 0 & - \\
\hline 20 & postmenopausal & HR+ HER2- & 2 & bone visceral & 2 & 0 & - \\
\hline 21 & postmenopausal & TNBC & 0 & visceral & 2 & 0 & - \\
\hline 22 & postmenopausal & HR+ HER2- & 2 & $\begin{array}{l}\text { bone lymph } \\
\text { nodes }\end{array}$ & 2 & 0 & - \\
\hline 23 & postmenopausal & HR+ HER2- & 2 & bone & 2 & 0 & - \\
\hline 24 & postmenopausal & HR+ HER2- & 1 & bone visceral & 2 & 0 & - \\
\hline 25 & premenopausal & HR+ HER2- & 0 & bone & 2 & 0 & - \\
\hline 26 & postmenopausal & HR+ HER2- & 1 & bone visceral & 1 & 1 (100)- & nucleus \\
\hline 27 & postmenopausal & HR+ HER2- & 0 & bone visceral & 1 & $1(100)$ & nucleus \\
\hline 28 & postmenopausal & HR+ HER2- & 3 & bone visceral & 1 & $1(100)$ & cytoplasm \\
\hline 29 & postmenopausal & HR+ HER2- & 0 & Lymph nodes & 1 & $1(100)$ & nucleus \\
\hline 30 & postmenopausal & HR+ HER2- & 7 & $\begin{array}{l}\text { Bone lymph } \\
\text { nodes }\end{array}$ & 1 & $1(100)$ & cytoplasm \\
\hline 31 & postmenopausal & HR+ HER2- & 0 & visceral & 1 & 0 & - \\
\hline 32 & postmenopausal & HR+ HER2- & 0 & bone visceral & 1 & 0 & - \\
\hline 33 & premenopausal & TNBC & 1 & visceral & 1 & 0 & - \\
\hline 34 & postmenopausal & HR+ HER2- & 0 & visceral & 1 & 0 & - \\
\hline 35 & postmenopausal & HR+ HER2- & 0 & visceral & 1 & 0 & - \\
\hline 36 & postmenopausal & TNBC & 1 & bone visceral & 1 & 0 & - \\
\hline 37 & postmenopausal & TNBC & 2 & visceral & 1 & 0 & - \\
\hline
\end{tabular}

${ }^{a}$ for metastatic disease 
rates of up to $25 \%$ being obtained [22, 24]. However, since $\mathrm{AR}$ expression is not routinely assessed on $\mathrm{BC}$ tissue, AR expression status of $\mathrm{MBC}$ is mostly unknown. Archived primary tumour tissue or a direct biopsy of the metastatic lesion is required to assess the AR expression status in cases where an AR-targeted therapy is considered [22, 24]. In light of this, CTCs might serve as a 'liquid biopsy' and an attractive non-invasive alternative to the biopsy of a metastasis [29]. We established a triple immunofluorescence staining for the AR in CTCs and show that ARpositive CTCs can be detected in the peripheral blood of MBC patients. These findings are concordant with recently published data by Fujii et al. [30]. We used the EpCAM-based CellSearch ${ }^{\circ}$ Profile kit for CTC detection to facilitate the identification of only tumour cells of epithelial origin. CTCs were further identified by direct visualisation of CK-positive, CD45-negative cells that contained an intact nucleus (DAPI positive). In our study, 16 out of 37 CTC-positive MBC patients (43\%) also yielded AR-positive tumour cells in the peripheral blood. This positivity rate is higher than in the study by Fujii et al., where $23 \%$ AR-positive CTCs were detected in CTC-positive MBC patients [30]. This discrepancy may be due to differences in patient characteristics. The majority of patients included in our trial had HR-positive disease (57/67 patients (85\%) compared to only $43 / 68$ patients (63\%) in the Fujii et al. study) and this subtype has been previously reported to be more likely to express AR $[7,14$, 30]. The AR positivity rate of CTCs in our small MBC cohort amounted $43 \%$. However, this positivity rate is lower than that reported for primary breast cancer tissue [7-14], which raises the question whether the AR status of CTCs coincides with that of the primary tumour. In the study by Fujii et al., three out of seven patients (43\%) demonstrated AR-positive CTCs despite AR-negative primary tumours [30]. Phenotypic differences between the primary tumour, metastatic lesions and CTCs, with regard to other predictive factors such as ER or HER2, are a known phenomenon $[28,31-34]$. Rocca et al. reported an overall concordance rate of $65 \%$ for AR expression between primary tumours and metastases [35]. Due to the lack of available tumour tissue (most of the patients were initially treated outside our centre), no comparison of the AR status between the CTCs and the corresponding tumour or metastatic lesion could be performed in our patients collective. However, as CTCs are an accepted non-invasive liquid biopsy [29], we hypothesize that the detection of AR-positive CTCs in MBC patients could be useful as a predictive factor for anti-AR treatment. The efficacy of targeting the AR in MBC patients with AR-positive CTCs need to be evaluated in further studies. Contrary to previously published analyses, we observed a heterogeneous localization of ARs in CTCs, with five out of 16 patients showing only nuclear AR staining and the majority (10 out of 16) only cytoplasmic staining. Both, nuclear and cytoplasmic staining was observed in CTCs from one patient. Previous studies defined AR positivity in the tumour tissue as a nuclear staining with a cut off value of $\geq 1 \%$ or $\geq 10 \%$ positive tumour cells regardless of intensity [11, 22, 36, 37]. In the analysis of the ARs in CTCs in BC patients, Fujii et al. also only counted nuclear localization of the receptor as positive [30]. However, heterogeneous subcellular localization of $\mathrm{AR}$ is a known phenomenon [5, 6]. Reyes et al. reported a common cytoplasmic AR localization in CTCs in metastatic castration-resistant prostate cancer patients [38]. The nuclear or cytoplasmic localization of the AR may reflect receptor activity, which mainly depends on the absence or presence of the ligand and was demonstrated to vary between cell lines [39-41]. Androgen serum levels in women are generally much lower than in men $[42,43]$, possibly leading to the reduced activity of the AR in breast cancer patients, which may explain the cytoplasmic localization of the receptor in some cases. On the other side, a postmenopausal status or an endocrine therapy with aromatase inhibitors increase serum levels of androgens in $\mathrm{BC}$ patients, which could result in AR activation and nuclear translocation $[44,45]$. Interestingly, only three out of five patients presenting CTCs with exclusively nuclear AR localization were postmenopausal, compared to nine out of ten patients with a solely cytoplasmic localization. Of note is the fact that none of these five cases received an aromatase inhibitor administration at the time of blood draw. The one patient presenting with both cytoplasmic and nuclear AR localization was a postmenopausal woman treated with letrozole at the time of sample collection. Another explanation of our findings could be the genetic aberration of the AR resulting in an impaired function of the receptor [46]. Specific mutations of the AR gene can diminish or abolish its nuclear translocation abilities despite ligand binding. Mutations can also cause constitutively active, nuclear-localised AR even in the absence of the ligand [47]. Another possible reason for cytoplasmic AR localization has been proposed by Koryakina et al. [48]. In their trial on the cell cycle dependent regulation of AR in prostate cancer cell lines, a cytoplasmic localization of the receptor was shown to be characteristic of mitotic cells [48]. This might explain the relatively high rate of cytoplasmatic localized AR in our study as mitotic CTCs seem to be a common event in advanced breast cancer [49]. Whether cytoplasmic ARs can be targeted by anti-AR drugs remains to be clarified [38]. In the recent study by Kumar et al., the AR nuclear staining in $\mathrm{BC}$ was shown to have the highest accuracy in predicting the anti-androgen therapy response, however, with a rather modest positive predictive value of 30\% [50]. In consideration of the above it is clear that the clinical relevance of heterogeneous subcellular AR localization in CTCs requires additional evaluative trials. 


\section{Conclusion}

The phenotypic characterization of CTCs, which might serve as a real-time liquid biopsy, is gaining in importance. This necessitates the identification of new predictive markers for systemic treatment in patients with MBC. The AR represents such a potential therapy target, since it is being expressed in all BC subtypes. In the present analysis we established a triple fluorescent staining of the AR in CTCs. The established robust method allowed for the direct visualization of the tumour cell and showed that AR-positive CTCs can be detected in MBC patients. AR localization in CTCs can vary and may be detected both in the nucleus and cytoplasm. Whether AR-positive CTCs are suitable to serve as a therapeutic biomarker and whether the pleiotropic AR localization has an impact on the efficacy of anti-AR agents in $\mathrm{MBC}$, need to be explored in future trials.

\section{Abbreviations}

AR: Androgen receptor; BC: Breast cancer; CK: Cytokeratin; CTC: Circulating tumour cell; DAPI: 4'6-diamidino-2-phenylindole; EpCAM: Epithelial cell adhesion molecule; FITC: Fluorescein isothiocyanate; HR: Hormone receptor; MBC: Metastatic breast cancer; PB : Peripheral blood; PBMC: Peripheral blood mononuclear cells; TNBC: Triple negative breast cancer

\section{Acknowledgements}

We thank Ruan van Rensburg, PhD, for revising the manuscript.

\section{Authors' contributions}

NK coordinated the study, performed the data analysis and drafted the manuscript. NM designed and performed the experiments, collected the data and helped to draft the manuscript. FMS, NH and ND coordinate the study, made substantial contribution to interpretation of the data and reviewed the manuscript. ER, SM, JH, TK, WJ were involved in collection of the data, drafting the manuscript or revising it. MBP, PR, IE made a substantial contribution to interpretation of the data and revised the manuscript. TF designed the study made substantial contribution to interpretation of the data and critically revised the manuscript. All authors read and approved the final manuscript.

\section{Funding}

none.

\section{Availability of data and materials}

The data that support the findings of this study are available from Tanja Fehm but restrictions apply to the availability of these data, which were used under license for the current study, and so are not publicly available. Data are however available from the authors upon reasonable request and with permission of Tanja Fehm.

\section{Ethics approval and consent to participate}

Written informed consent to participate was obtained from all patients. The study was approved by the Ethical Committee of the Eberhard Karls University of Tuebingen (responsible for DETECT III: 525/2011AMG1) and the local Ethical Committee of the Heinrich Heine University of Duesseldorf (DETECT III: MC-531; DETECT IV: MC-LKP-668).

\section{Consent for publication}

This manuscript does not contain any details, images, or videos that might leed to identification of an individual patient. A written informed consent to publish the results od the study -without identifying any participants-was obtained from all the patients.

\section{Competing interests}

The authors declare that there are no conflicts of interest.

\section{Author details}

1 Department of Obstetrics and Gynaecology, University of Duesseldorf, Moorenstr. 5, 40225 Duesseldorf, Germany. 'Department of Obstetrics and Gynaecology, Asklepios Klinik Barmbek, Rübenkamp 220, 22307 Hamburg, Germany. ${ }^{3}$ Department of Pathology, University of Duesseldorf, Moorenstr. 5, 40225 Duesseldorf, Germany. ${ }^{4}$ Department of Obstetrics and Gynaecology, University of Ulm, Prittwitzstraße 43, 89075 Ulm, Germany.

Received: 19 January 2019 Accepted: 31 October 2019

Published online: 12 November 2019

\section{References}

1. Ferlay J, et al. Cancer incidence and mortality worldwide: sources, methods and major patterns in GLOBOCAN 2012. Int J Cancer. 2015;136(5):E359-86.

2. Early Breast Cancer Trialists' Collaborative, G. Effects of chemotherapy and hormonal therapy for early breast cancer on recurrence and 15year survival: an overview of the randomised trials. Lancet. 2005; 365(9472):1687-717.

3. Clarke $M$, et al. Effects of radiotherapy and of differences in the extent of surgery for early breast cancer on local recurrence and 15-year survival: an overview of the randomised trials. Lancet. 2005;366(9503):2087-106.

4. Prescott J, Coetzee GA. Molecular chaperones throughout the life cycle of the androgen receptor. Cancer Lett. 2006;231(1):12-9.

5. Heemers HV, Tindall DJ. Androgen receptor (AR) coregulators: a diversity of functions converging on and regulating the AR transcriptional complex. Endocr Rev. 2007;28(7):778-808.

6. Kumar R, McEwan IJ. Allosteric modulators of steroid hormone receptors: structural dynamics and gene regulation. Endocr Rev. 2012;33(2):271-99.

7. Isola JJ. Immunohistochemical demonstration of androgen receptor in breast cancer and its relationship to other prognostic factors. J Pathol. 1993; 170(1):31-5.

8. Brys M. Androgens and androgen receptor: do they play a role in breast cancer? Med Sci Monit. 2000;6(2):433-8.

9. Liao DJ, Dickson RB. Roles of androgens in the development, growth, and carcinogenesis of the mammary gland. J Steroid Biochem Mol Biol. 2002; 80(2):175-89.

10. Park $\mathrm{S}$, et al. Expression of androgen receptors in primary breast cancer. Ann Oncol. 2010;21(3):488-92.

11. Ogawa $Y$, et al. Androgen receptor expression in breast cancer: relationship with clinicopathological factors and biomarkers. Int J Clin Oncol. 2008;13(5):431-5.

12. Loibl S, et al. Androgen receptor expression in primary breast cancer and its predictive and prognostic value in patients treated with neoadjuvant chemotherapy. Breast Cancer Res Treat. 2011;130(2):477-87.

13. Hu R, et al. Androgen receptor expression and breast cancer survival in postmenopausal women. Clin Cancer Res. 2011:17(7):1867-74.

14. Collins $L C$, et al. Androgen receptor expression in breast cancer in relation to molecular phenotype: results from the Nurses' health study. Mod Pathol. 2011;24(7):924-31.

15. Birrell $\mathrm{SN}$, et al. Androgens induce divergent proliferative responses in human breast cancer cell lines. J Steroid Biochem Mol Biol. 1995;52(5): 459-67.

16. Hackenberg $R$, et al. Androgen sensitivity of the new human breast cancer cell line MFM-223. Cancer Res. 1991;51(20):5722-7.

17. Need EF, et al. Research resource: interplay between the genomic and transcriptional networks of androgen receptor and estrogen receptor alpha in luminal breast cancer cells. Mol Endocrinol. 2012;26(11):1941-52.

18. Szelei J, et al. Androgen-induced inhibition of proliferation in human breast cancer MCF7 cells transfected with androgen receptor. Endocrinology. 1997; 138(4):1406-12.

19. Goldenberg IS, et al. Combined androgen and antimetabolite therapy of advanced female breast cancer. A report of the cooperative breast cancer group. Cancer. 1975;36(2):308-10.

20. De Amicis F, et al. Androgen receptor overexpression induces tamoxifen resistance in human breast cancer cells. Breast Cancer Res Treat. 2010;121(1):1-11

21. Rahim B, O'Regan R. AR Signaling in Breast Cancer. Cancers (Basel). 2017;9(3).

22. Gucalp A, et al. Phase II trial of bicalutamide in patients with androgen receptor-positive, estrogen receptor-negative metastatic breast Cancer. Clin Cancer Res. 2013;19(19):5505-12. 
23. Traina TA, et al. Enzalutamide for the treatment of androgen receptorexpressing triple-negative breast Cancer. J Clin Oncol. 2018;36(9):884-90.

24. Traina T, T., KM., Denise AY., Joyce O'Shaughnessy, JC., Ahmad A., Catherine MK., Maureen ET., Peter S., Luca Gianni, LG., Rita N., Foluso OA., Stephen C., Joyce LS., Martha EB., lulia CT., Hirdesh Uppal, ACP., Clifford AH., Results from a phase 2 study of enzalutamide (ENZA), an androgen receptor (AR) inhibitor, in advanced AR+ triple-negative breast cancer (TNBC). . 2015 ASCO annual meeting; 2014; Chicago, IL.

25. Bidard FC, et al. Clinical validity of circulating tumour cells in patients with metastatic breast cancer: a pooled analysis of individual patient data. Lancet Oncol. 2014

26. Pantel $K$, Alix-Panabieres C. Real-time liquid biopsy in cancer patients: fact or fiction? Cancer Res. 2013;73(21):6384-8.

27. Schramm A, et al. Therapeutic intervention based on circulating tumor cell phenotype in metastatic breast cancer: concept of the DETECT study program. Arch Gynecol Obstet. 2016;293(2):271-81.

28. Fehm T, et al. HER2 status of circulating tumor cells in patients with metastatic breast cancer: a prospective, multicenter trial. Breast Cancer Res Treat. 2010;124(2):403-12.

29. Krawczyk N, et al. Liquid biopsy in metastasized breast Cancer as basis for treatment decisions. Oncol Res Treat. 2016:39(3):112-6.

30. Fujii T, et al. Androgen receptor expression on circulating tumor cells in metastatic breast cancer. PLoS One. 2017;12(9):e0185231.

31. Kalinsky K, et al. Correlation of hormone receptor status between circulating tumor cells, primary tumor, and metastasis in breast cancer patients. Clin Transl Oncol. 2015;17(7):539-46.

32. Babayan A, et al. Heterogeneity of estrogen receptor expression in circulating tumor cells from metastatic breast cancer patients. PLoS One 2013;8(9):e75038.

33. Pestrin $\mathrm{M}$, et al. Correlation of HER2 status between primary tumors and corresponding circulating tumor cells in advanced breast cancer patients. Breast Cancer Res Treat. 2009;118(3):523-30.

34. Wallwiener $\mathrm{M}$, et al. The impact of HER2 phenotype of circulating tumor cells in metastatic breast cancer: a retrospective study in 107 patients. BMC Cancer. 2015;15:403.

35. Rocca, A., et al., Is androgen receptor useful to predict the efficacy of antiestrogen therapy in advanced breast cancer? 2017.

36. He J, et al. Prognostic value of androgen receptor expression in operable triple-negative breast cancer: a retrospective analysis based on a tissue microarray. Med Oncol. 2012;29(2):406-10.

37. Safarpour D, Pakneshan S, Tavassoli FA. Androgen receptor (AR) expression in 400 breast carcinomas: is routine AR assessment justified? Am J Cancer Res. 2014;4(4):353-68.

38. Reyes EE, et al. Quantitative characterization of androgen receptor protein expression and cellular localization in circulating tumor cells from patients with metastatic castration-resistant prostate cancer. J Transl Med. 2014;12:313.

39. Georget $V$, et al. Trafficking of the androgen receptor in living cells with fused green fluorescent protein-androgen receptor. Mol Cell Endocrinol. 1997;129(1):17-26.

40. Nakauchi $H$, et al. A differential ligand-mediated response of green fluorescent protein-tagged androgen receptor in living prostate cancer and non-prostate cancer cell lines. J Histochem Cytochem. 2007;55(6):535-44.

41. Wetherill $Y B$, et al. The xenoestrogen bisphenol a induces inappropriate androgen receptor activation and mitogenesis in prostatic adenocarcinoma cells. Mol Cancer Ther. 2002;1(7):515-24.

42. Bhasin $\mathrm{S}$, et al. Reference ranges for testosterone in men generated using liquid chromatography tandem mass spectrometry in a community-based sample of healthy nonobese young men in the Framingham heart study and applied to three geographically distinct cohorts. J Clin Endocrinol Metab. 2011;96(8):2430-9.

43. Haring $R$, et al. Age-specific reference ranges for serum testosterone and androstenedione concentrations in women measured by liquid chromatography-tandem mass spectrometry. J Clin Endocrinol Metab. 2012; 97(2):408-15.

44. Dimitrakakis C, Bondy C. Androgens and the breast. Breast Cancer Res. 2009; 11(5):212.

45. Kyvernitakis I, et al. Effect of anastrozole on hormone levels in postmenopausal women with early breast cancer. Climacteric. 2015: 18(1):63-8.

46. Eisermann $\mathrm{K}$, et al. Androgen receptor gene mutation, rearrangement, polymorphism. Transl Androl Urol. 2013;2(3):137-47.
47. Jenster $\mathrm{G}$, et al. Domains of the human androgen receptor involved in steroid binding, transcriptional activation, and subcellular localization. Mol Endocrinol. 1991;5(10):1396-404.

48. Koryakina Y, Knudsen KE, Gioeli D. Cell-cycle-dependent regulation of androgen receptor function. Endocr Relat Cancer. 2015;22(2):249-64.

49. Adams DL, et al. Mitosis in circulating tumor cells stratifies highly aggressive breast carcinomas. Breast Cancer Res. 2016;18(1):44.

50. Kumar, V., Yu, J., Phan, V., Tudor, I. C., Peterson, A, Uppal, H., Androgen Receptor Immunohistochemistry as a Companion Diagnostic Approach to Predict Clinical Response to Enzalutamide in Triple-Negative Breast Cancer. DOI: https://doi.org/10.1200/PO.17.00075 JCO Precision Oncology published online October 10, 2017, 2017.

\section{Publisher's Note}

Springer Nature remains neutral with regard to jurisdictional claims in published maps and institutional affiliations.
Ready to submit your research? Choose BMC and benefit from:

- fast, convenient online submission

- thorough peer review by experienced researchers in your field

- rapid publication on acceptance

- support for research data, including large and complex data types

- gold Open Access which fosters wider collaboration and increased citations

- maximum visibility for your research: over $100 \mathrm{M}$ website views per year

At BMC, research is always in progress.

Learn more biomedcentral.com/submissions 